\title{
KONSEP ARSITEKTUR PANTI REHABILITASI KETERGANTUNGAN NARKOTIKA \& PSIKOTROPIKA DI MAKASSAR, PENDEKATAN ARSITEKTUR POSTMODERN HISTORISCM
}

\author{
Adrianto Hidayat ${ }^{1)}$ Amiruddin Akbar Fisu ${ }^{2)}$ \\ 1) Universitas Hasanuddin, Makassar ${ }^{2)}$ Universitas Andi Djemma ,Palopo \\ 1) hidayat.adrean@gmail.com ${ }^{2)}$ amiruddinakbarfisu07@gmail.com
}

\begin{abstract}
ABSTRAKSI
Penyalahgunaan narkotika dan obat-obatan terlarang dalam perundang-undangan dinilai tindakan kriminalitas. Di sisi lain juga sebagai penyakit sosial yang berdampak pada hubungan manusia antarsesama, terhadap lingkungan dan juga Tuhan. Norma-norma adat, aturan-aturan tidak tertulis dalam masyarakat. Olehnya itu pengadaan panti rehabilitasi Narkotika dan Psikotropika ini diharapakan menjadi wadah pembinaan untuk menghentikan kecanduan/ketergantungan di bawah pengaruh narkotika, psikotropika dan obat-obatan lainnya. Penyediaan fasilitas-fasilitas fisik desain diperlukan untuk membina dan mengembalikan pengguna narkotika seperti sebelumnya; terlepas dari hukuman baik formal konstitusional maupun norma-norma susila yang tak tertulis. Langgam arsitektur postmodern historicism sebagai pendekatan desain bangunan diharapkan mampu memberikan nuansa berbeda sebagai bentuk adaptasi secara tidak langsung terhadap residen dalam hal melakukan proses pemulihan. Dengan melihat, menetap sementara di bangunan dengan konsep tidak seperti biasanya atau dengan kata lain sebagai sesuatu yang baru, residen siap memasuki hidup yang baru pula. Tentunya dengan pelayanan baik dan perawatan yang intensif. Kompleks bangunan panti ini direncanakan pada lahan seluas kurang lebih 4,3 Ha yang terletak di Kecamatan Manggala, Kota Makassar. Pemilihan lokasi didasarkan atas perencanaan rencana tata ruang berjenis pelayanan sosial dan pemukiman. Akses mudah, pencapaian pun demikian. Panti rehabilitasi ini direncanakan bermassa, di antaranya unit medik, unit rehabilitasi psikososial, psikologi, psikoreligi dan juga unit hunian. Keenam unit tersebut dihubungkan oleh ruang luar, sekaligus ruang-ruang sosial. Secara umum, bangunan ini termasuk dalam jenis hunian dan kesehatan.
\end{abstract}

Kata Kunci: Rehabilitasi, Hunian, Postmodern, Arsitektur

\section{PENDAHULUAN}

Indonesia telah mengalami kemajuan sebagai Negara berkembang. Hal demikian menyebabkan modernisasi pemikiran dari mayarakat urban menjadi masyarakat modern.

Ciri-ciri masyarakat modern. Tindakan-tindakan sosial; dalam masyarakat tradisional, tindakan sosial lebih bersandar pada kebiasaan atau tradisi atau prescribe action. Dalam masyarakat modern, tindakan-tindakan sosial akan lebih banyak bersifat pilihan. Berkembangnya organisasi dan differensiasi. Sistem sosial dalam masyarakat modern, hubungan primer antarindividu telah jauh berkurang dan hubungan sekunder yang lebih bersifat impersonal menjadi lebih predominan.

Dalam masyararakt tradisional, status, hubungan dan keterkaitan sosial lebih didasarkan pada apa atau siapa seseorang; latar belakang keluarga atau keturunan, suku atau ras, gender dan usia. Sedangkan pada masyarakat modern apa dan siapa bukannya sama sekali diabaikan, tetapi bobotnya kurang dibandingkan dengan prestasi dan potensi yang telah dicapai. Penghargaan terhadap kemampuan fisik tidak juga diabaikan, tetapi penghargaan lebih besar diberikan kepada kemampuan intelektual.

Kedudukan Makassar sebagai pintu gerbang Indonesia bagian timur yang membuka peluang perkembangan dari banyak aspek kehidupan manusia. Perkembangan itu kemudian tentunya serta merta menimbulkan masalah-masalah yang cukup kompleks. Diantaranya, Makassar tahun 2011 menempati peringkat delapan sebagai pengguna narkotika terbesar seluruh Indonesia yang pada tahun sebelumnya diperingkat 20 . Hal demikian membuktikan kota-kota besar selalu menjadi incaran peredaran gelap narkotika dan obat-obatan terlarang lainnya.

Narkotika dan Psikotropika telah merusak tatanan sosial yang juga berdampak kepada pembangunan, mengingat masyarakat terdiri dari individu-individu. Pengguna cenderung menarik diri akibat dari tekanan sosial dan psikis sebab tak diterima lagi dalam masyarakat. Terlebih pengguna narkotika ini adalah remaja dimana sedang dalam masa produktif.

Ketika Permasalah-permasalahan itu dibenturkan dengan dengan kebutuhan dasar manusia (teori maslow) dengan piramida dimana kebutuhan yang paling puncak yaitu (1) aktualisasi diri, disusul (2) penghargaan diri, (3) berinteraksi sosial, (4) rasa aman dan (5) kebutuhan akan sandang, pangan, papan dan pangan. Dalam hal ini akan dibahas tentang tingkatan kebutuhan paling atas dan bawah. Bangunan yang dapat dirasa secara visual sebagai kebutuhan manusia akan papan; satu tempat berlindung dan bertempat tinggal. Setelah pemenuhan tempat rehabilitasi terhadap pengyalahguna narkotika ternyata ada hal yang lebih substansial yang tidak kalah pentingnya, yaitu aktualisasi diri. 
Bagi Pengguna yang telah pulih total dari penyalahgunaan Narkotika penting baginya untuk dengan mudah beradaptasi kembal; utamanya segera dapat diterima keberadaannya di tengah-tengah masyarakat, dihargai dan beraktualisasi diri. Sikap apatis masyarakat saat ini yang cenderung memberi dampak negatif. Bagaimana kemudian seseorang dapat dihargai sedangkan kemampuan mereka terbatasi dengan kondisi lingkungan dan psikis yang labil di bawah pengaruh narkotika.

\section{STUDI BANDING}

\section{Betty Ford Centre}

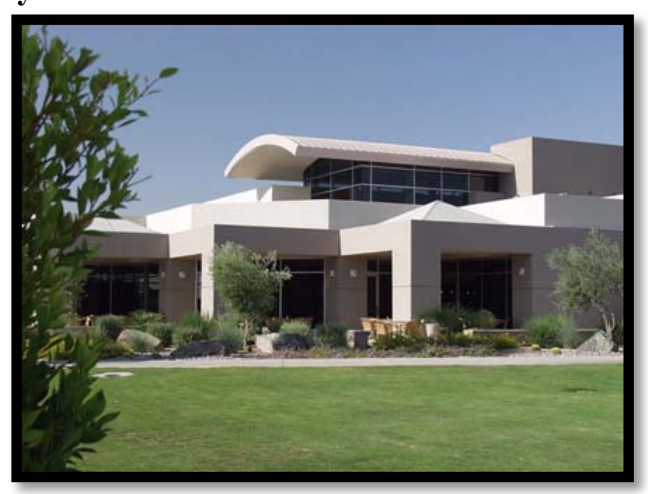

Terbangun di atas lahan seluas 20 are dengan menggunakan dua belas Langkah sebagai basis dari metodologi terapi program mereka dengan penerapan yang dapat diklasifikasikan sebagai Minnesota Model of Treatment. Di dunia internasional, model ini, atau bentuk yang serupa, sudah diterapkan di hampir semua negara Eropa, Australia, dan beberapa negara di Asia seperti India, Saudi Arabia dan Filipina.

\section{Entrance Utama Betty Ford}

Karakteristik Model Abstinensi total atau berpantang penuh dari segala jenis narkoba dan alkohol, serta perubahan cara hidup adalah tujuan dari program ini. Jangka masa program biasanya tidak lama, antara 1-3 bulan untuk masa rawatan awal, dan apabila diperlukan, masa akan ditambah selama 2-4 bulan lagi dalam fase yang disebut sebagai Extended Care. Bentuk aplikasi dari model ini cukup variatif, tetapi semuanya mempunyai target yang sama, yaitu bagaimana seorang pecandu atau alkoholik dapat menerima kondisi dirinya, mengenali kekuatan dan kelemahan serta faktor pendukung yang ada, dan menunjukkan kemauan untuk menjalani proses pemulihannya dengan berpartisipasi sebagai anggota dalam komunitas 12 Langkah seperti AA dan NA. Minnesota model memandang dan memperlakukan ketergantungan terhadap Narkoba dan alkohol berdasarkan paradigma Disease Model of Addiction, di mana adiksi dianggap sebagai suatu penyakit fisik, mental, dan terutama spiritual yang bersifat kronis, artinya akan dapat kambuh kembali sewaktu-waktu. Karena target dari model ini bukanlah perubahan perilaku dan cara berpikir secara total, maka jangka masa program menjadi tidak terlalu panjang. Pada akhir rawatan, klien hanya diharapkan mempunyai keyakinan terhadap program 12 Langkah sebagai solusi dan upaya untuk memelihara kebersihannya. Perubahan perilaku dan cara berpikir akan terwujud setelah si klien mengalami pertumbuhan dengan menjalani program 12 Langkah, suatu proses yang memang memakan waktu lama dan berjalan sepanjang hidup klien setamatnya dari program rehabilitasi.

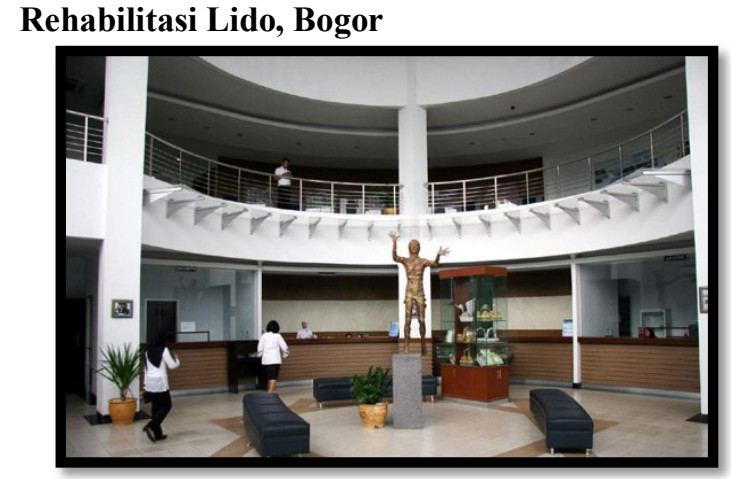

Lobby Utama Rehablitasi Lido
Panti rehabilitasi berkapasitas 500 residen atau pecandu yang terletak di Lido Bogor.Di pusat rehabilitasi ini tersedia fasilitas seperti olahraga, pusat keterampilan hingga kegiatan sosial yang berdiri di atas tanah seluas $112.000 \mathrm{~m} 2$. Ada tahapantahapan yang akan dilalui pasien yang baru masuk hingga akhirnya dinyatakan sembuh total. Tiga tahapan yang dimaksud adalah tahapan Healing, Revolution dan Transformation. Tahapan pertama, pasien akan menjalani detoksifikasi atau putus zat dengan terapi simptomik secara berkelanjutan selama satu bulan. Setelah itu, residen akan menjalani program primary selama 6 bulan. 


\section{Sunset Malibu}

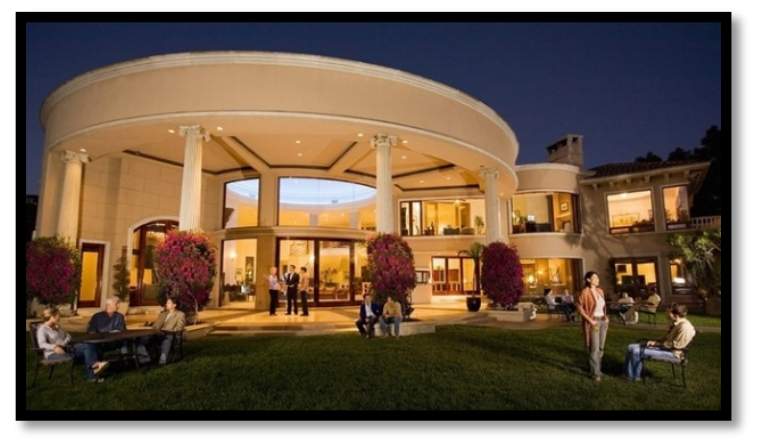

\section{Rehablitasi Baddoka, Makassar}

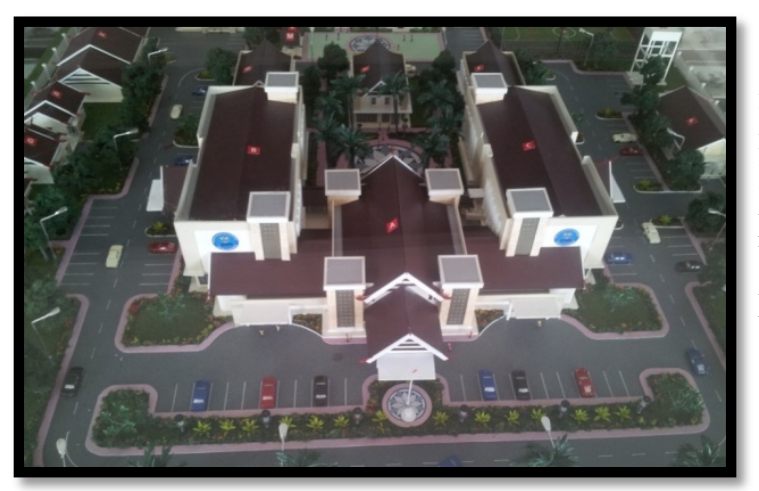

Lantai 1 digunakan untuk dua kegiatan utama, yaitu,

1) Kegiatan Rehabilitasi; ruang-ruang dibuat untuk mendukung kegiatan rehabilitasi yang terjadi di dalam bangunan seperti ruang detoksifikasi, ruang konseling, ruang hypnoteraphy, perpustakaan dan sebagainya.

2) Kegiatan Service; ruang service yang berada di lantai ini adalah tungku perapian, dapur, ruang makan, ruang massages, akupuntur, serta beberapa juice bar.

Lantai 2 digunakan untuk kegiatan-kegiatan yang bersifat pribadi. Terdapat 12 buah kamar tidur yang masing-masing memiliki kamar mandi dan fasilitas tv kabel. Kamar tidur didesain dengan interior yang memiliki detail dengan material kayu dan view langsung ke samudra pasifik

Metode rehabilitasi yang diterapkan hamper sama di setiap panti rehabilitasi lainnya. Secara umum terdiri dari rehabilitasi medic, rehabilitasi psikologi, rehabilitasi psikososial dan rehabilitasi religius.

Adapun Fasilitas-fasilitas yang meengkapi bangunan tersebut adalah, Bagian terapi \& pengelola, Gedung rehabilitasi residen pria, Gedung rehabilitasi residen wanita, Halfway residen pria \& wanita, Mess karyawan, Rumah dinas dokter, Workshop, Laundry, Tempat beribadah seperti masjid, gereja, wihara, dan pura; Rumah jenazah, Lapangan outdoor, guest house dan Gedung serba guna.

\section{STUDI LITERATUR}

ciri-ciri dan karakter arsitektur historicism itu,

a) Mengambil kembali gaya/karakter sejarah. Seperti dengan menggunakan kembali pilar-pilar khas yunani dan romawi. Termasuk di dalamnya ionik, dorik dan corintin.

b) Menggunakan desain interior yang antik dan tidak seperti biasanya. Menggunakan banyak ornamen. pengeksposan upperstruktur terjadi pada bagian bangunan tertentu.

c) Penggunaan warna yang cenderung perpaduan warna-warna cerah. Lantai dan dinding sengaja dibuat kontras.

d) Memiliki skala monumental.

e) Pada bagian-bagian tertentu, terlihat simetris. Seperti pada tampak entrance utama.

f) Untuk bangunan yang bermassa banyak, digunakan koridor sebagai titik-titik penghubung dari bangunan satu ke bangunan lainnya.

g) Penggunaan kanopi yang lebih sering disebut mansonry dan architrave pada jendela-jendela. Baik mansonry arch, segmental maupun mansonry jack.

Adapun faktor-faktor nonarsitektural yang perlu diperhatikan adalah

a) Fungsi bangunan sebagai pelayanan sosial

b) Merupakan sarana pembinaan dan pendidikan untuk mengatasi residen penyalahgunaan narkotika 
c) Kesan hangat, aktif dan monumental. Monumental disini bukan berarti selalu berhubungan dengan skala megah dibanding skala manusia. Dengan memandang secara luas lagi, monumen berarti ada cipta berkesan, rasa teringat karena sesuatu hal yang tidak biasanya, tidak lumrah, jarang bahkan sesuatu yang baru.

\begin{tabular}{|c|c|c|c|c|c|c|c|}
\hline & \multicolumn{7}{|c|}{ UNSUR DESAIN } \\
\hline & STRUKTUR & SKALA & SUASANA & WARNA & INTERIOR & $\begin{array}{l}\text { EKSTERIOR DAN } \\
\text { RUANG LUAR }\end{array}$ & TATA MASSA \\
\hline 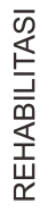 & $\begin{array}{c}\text { TIDAK RUMIT } \\
\text { MENGIKUTI LANGGAM }\end{array}$ & $\begin{array}{l}\text { MEMANUSIAKAN } \\
\text { MANUSIA }\end{array}$ & $\begin{array}{c}\text { TENANG, } \\
\text { KEKELUARGAAN, } \\
\text { BERASA DI RUMAH } \\
\text { SENDIRI, TIDAK } \\
\text { SEPERTI PENJARA \& } \\
\text { BERSIFAT MEMBATASI }\end{array}$ & $\begin{array}{l}\text { WARNA SEJUK, } \\
\text { UNTUK KETENANGAN } \\
\text { PASIEN; TIDAK } \\
\text { MENYILAUKAN }\end{array}$ & $\begin{array}{c}\text { FURNITURE MUDAH } \\
\text { MAINTENNANCE, TIDAK } \\
\text { RUMIT, TIDAK } \\
\text { MEMBAHAYAKAN } \\
\text { PASIEN }\end{array}$ & $\begin{array}{c}\text { SEPENUHNYA } \\
\text { MENGIKUTI LANGGAM, } \\
\text { TERSEDIA RUANG } \\
\text { TERBUKA, RUANG LUAR } \\
\text { SEBAGAIBAGIAN DARI } \\
\text { AKTIVITAS FUNGSI. }\end{array}$ & $\begin{array}{l}\text { SELF ENCLOSING, } \\
\text { BANGUNAN-BANGUNAN } \\
\text { SEBAGAI PEMBATAS } \\
\text { TIDAK LANGSUNG. } \\
\text { KEAMANAN YANG } \\
\text { TINGGI DAN MUDAH } \\
\text { DIKONTROL }\end{array}$ \\
\hline 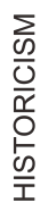 & $\begin{array}{l}\text { MENGGUNAKAN } \\
\text { PILAR-PILAR BESAR, } \\
\text { EKSPOS UPPER, } \\
\text { KOLOM YANG } \\
\text { BERDEKATAN, } \\
\text { SIMETRIS }\end{array}$ & MONUMENTAL & $\begin{array}{c}\text { PENEGASAN RUANG, } \\
\text { TIDAK RUMIT, } \\
\text { SIRKULASI JELAS DAN } \\
\text { MUDAH }\end{array}$ & $\begin{array}{l}\text { MENGGUNAKAN } \\
\text { WARNA KONTRAS } \\
\text { UNTUK BIDANG-- } \\
\text { BIDANG YANG BEDA }\end{array}$ & $\begin{array}{l}\text { FURNITURE ANTIK, } \\
\text { BANYAK ORNAMEN }\end{array}$ & $\begin{array}{c}\text { EKSPOS STRUKTUR } \\
\text { PILAR ENTARANCE } \\
\text { UTAMA, RUANG LUAR } \\
\text { DAN KORIDOR } \\
\text { PEMBENTUK RUANG } \\
\text { SEMU }\end{array}$ & $\begin{array}{c}\text { SIMETRIS, } \\
\text { PENGGUNAAN } \\
\text { KORIDOR SEBAGAI } \\
\text { PENGHUBUNG } \\
\text { ANTARBANGUNAN BAIK } \\
\text { ITU FISIK MAUPUN } \\
\text { VEGETASI }\end{array}$ \\
\hline 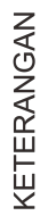 & $\begin{array}{l}\text { PILAR-PILAR BESAR } \\
\text { DIEKSPOS, KOLOM } \\
\text { UTAMA MENGIKUTI } \\
\text { KEBUUUHAN RUANG }\end{array}$ & $\begin{array}{c}\text { SKALA MODERAT, } \\
\text { DISESUAIKAN } \\
\text { DENGAN PENGGUNA } \\
\text { BANGUNAN }\end{array}$ & $\begin{array}{l}\text { PEMISAHAN RUANG } \\
\text { BERDASARKAN } \\
\text { FUNGSI, MENAMBAH } \\
\text { JALUR-JALUR } \\
\text { SIRKULASI, RUANG } \\
\text { TERBUKA YANG } \\
\text { MAKSIMAL. }\end{array}$ & $\begin{array}{l}\text { PERPADUAN WARNA. } \\
\text { KOMPOSISI WARNA } \\
\text { BERNUANSAALAM, } \\
\text { MERAH BATA, HIJAU, } \\
\text { PUTIH \& PASTEL } \\
\text { LAINNYA. }\end{array}$ & $\begin{array}{c}\text { STANDARDISASI } \\
\text { KESEHATAN YANG } \\
\text { JELAS, SOLID VOID, } \\
\text { ORNAMEN } \\
\text { DIPERTAHANKAN PADA } \\
\text { RUANG-RUANG } \\
\text { TERTENTU. }\end{array}$ & $\begin{array}{l}\text { MEMAKSIMALKAN } \\
\text { RUANG LUAR/TERBUKA } \\
\text { SEBAGAI RUANG- } \\
\text { RUANG SOSIAL, PILAR- } \\
\text { PILAR TETAP } \\
\text { DIPERTAHANKAN. }\end{array}$ & $\begin{array}{l}\text { TATA MASSA SALING } \\
\text { TERIKAT/MENUTUPI } \\
\text { PANDANGAN. KORIDOR } \\
\text { SEBAGAI JALUR } \\
\text { PENGHUBUNG } \\
\text { ANTARMASSA }\end{array}$ \\
\hline
\end{tabular}

\section{KONSEP DASAR}

\section{Sasaran Proyek}

\section{Pembahasan}

Merancang bangunan yang dapat memenuhi tuntutan dalam fungsi sebagai panti rehabilitasi ketergantungan narkotika dan psikotropika di Makassar dan Indonesia TImur umumnya.

\section{Pelaku Kegiatan}

- Pasien

Pihak yang sedang menjalani proses rehabilitasi

- Pengelola

Pihak yang mengurus administrasi, maintenanncepanti rehabilitasi

- $\quad$ Dokter, psikiater, psikolog

Pihak yang memiliki kemampuan menjalanakan pengobatan dalam metode rehabilitasi.

- Pengunjung, keluarga pasien

Pihak yang datang ke panti untuk membesuk pasien sekaligus mendapatkan pelatihan/penyuluhan mengenai penyalahgunaan narkotika 


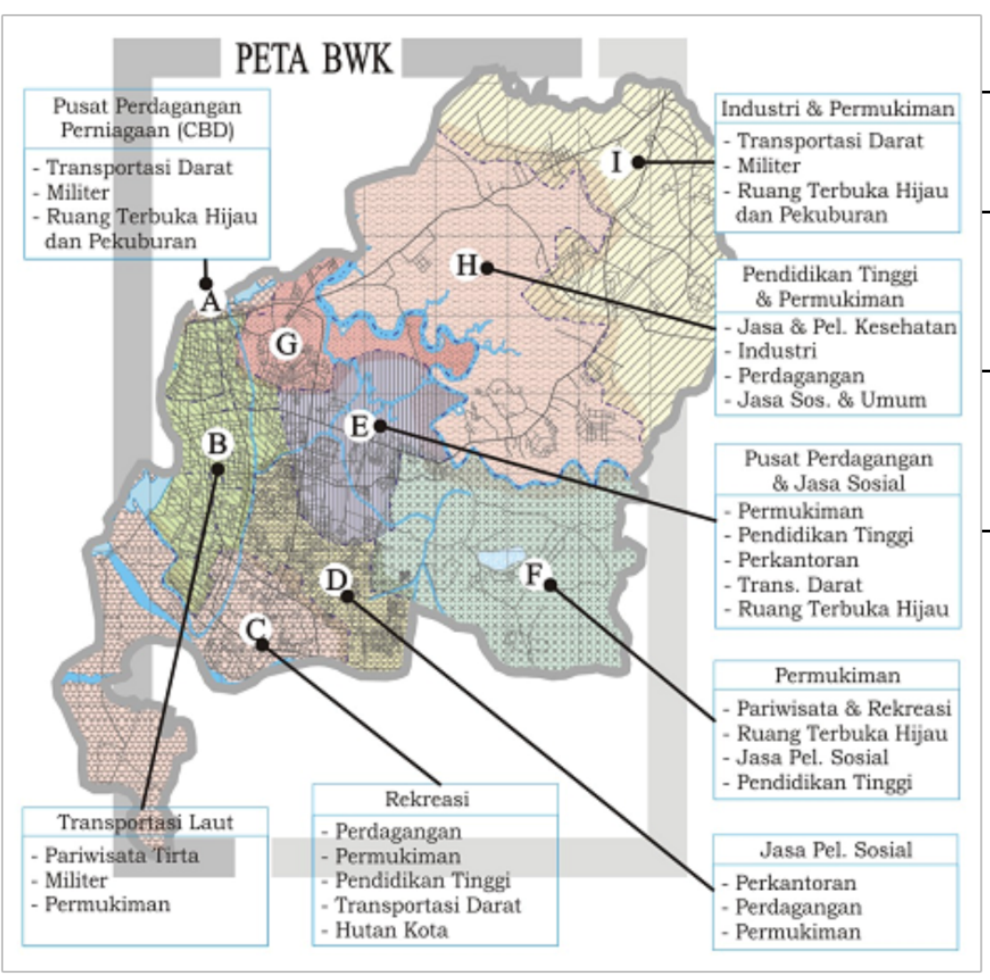

- Sesuai dengan rencana tata ruang Kota Makassar dengan peruntukan lahan dengan jasa permukiman, pelayanan sosial, dan pemanfaatan ruang-ruang terbuka hijau sebagai bagian dari aktivitas utama.

- Dilalui oleh jalur transportasi umum kota

- Terletak di kawasan dengan tingkat pemukiman dengan kepadatan penduduk yang rendah samapi sedang/menengah.

- Lingkungan dengan kualitas udara yang cukup bersih, bukan di daerah industri dan pusat perkotaan.

- Suasana tenang, mendukung untuk mejalankan proses penyembuhan pasien.

- Ketersediaan lahan pembangunan.

- Tersedianya utilitas kota seperti sanitasi, air PAM, listrik dan jaringan telepon.
- Sesuai dengan rencana umum Tata ruang Kota Makassar. Panti rehabilitasi Narkotika ini termasuk dalam kategori jasa pelayanan sosial.

Lokasi harus mudah dicapai oleh kendaraan umum; memudahkan pencapaian baik pengunjung maupun pasien.

Terletak pada daerah yang tidak padat; hal ini mendukung proses penyembuhan pasien. Menyangkut kenyamanan dan ketentraman suasana perehabilitasian.

Adanya lahan kosong; lahan yang memungkinkan mendirikan sebuah panti rehabilitasi baik dari segi luas lahan maupun pertimbangan syarat sebuah panti.

Tersedianya utilitas kota

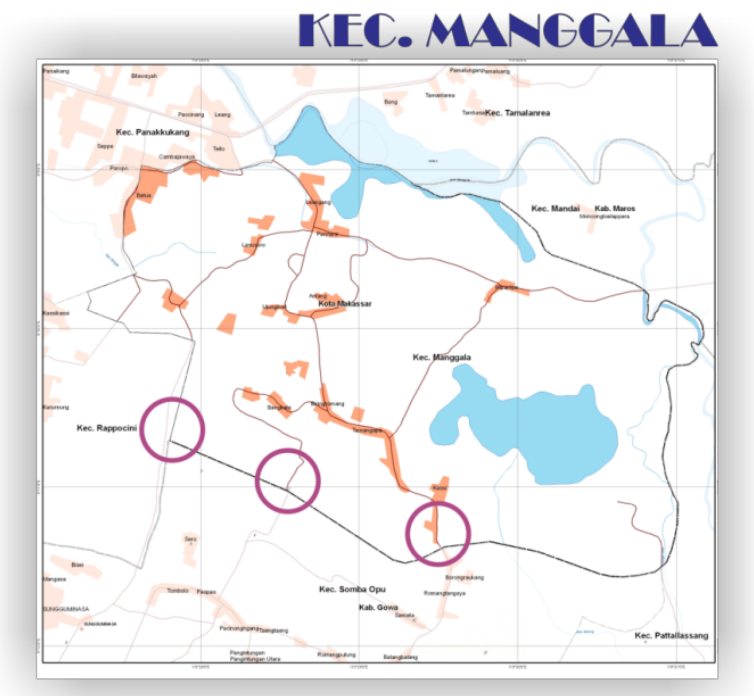

\section{Tapak Terpilih}

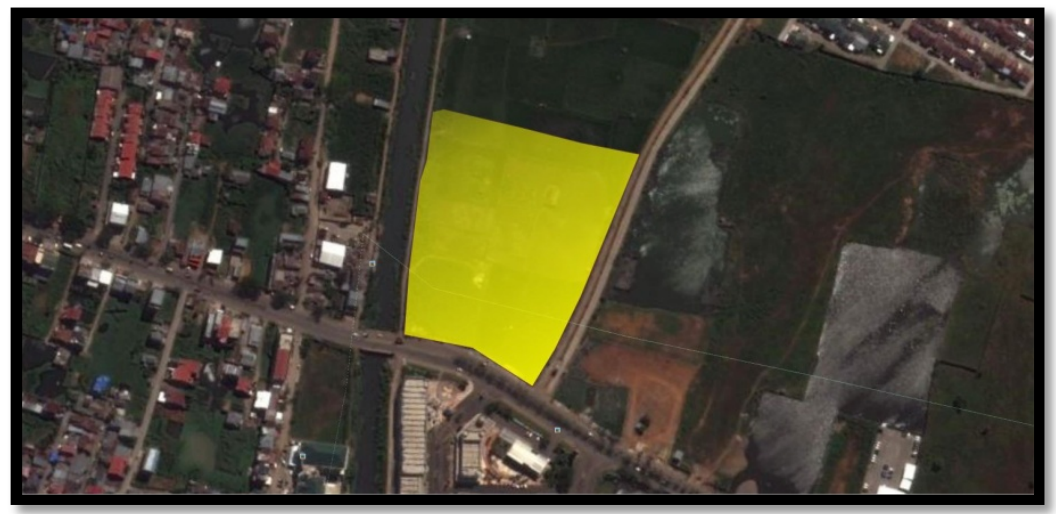

Kriteria Tapak,

1. Luasan tapak mencukupi.

2. Memiliki jalan alternatif baik itu setapak maupun jalan utama.

3. Terjangkau oleh kendaraan pribadi/umum

4. Adanya utilitas kota yang mendukung.

5. Tapak dengan kepadatan penduduk yang relatif rendah/menengah.

6. Lahan dengan topografi yang datar/landai. 
1. Sirkulasi dan Pencapaian

Agar tidak mengganggu dalam runitinas kegiatan, maka prinsipnya sirkulasi dan pencapaian dalam Panti Rehabilitas Narkotika perlu dipisahkan antara keduanya:

a) Pengunjung (ke ruang ruang konsultasi, ruang serbaguna, office)

b) Pengelola rehabilitasi (service/staff/karyawan, social worker)

Berdasarkan rencana dan besarnya jalan yang ada dan diperkirakan datangnya pengunjung terlalu banyak ditinjau dari sistem sirkulasi dan kemudahan pencapaian. Sistem sirkuasi pada tapak didasarkan atas pertimbangan sebagai berikut.

a) Kemudahan dan kenyamanan pelaku kegiatan, khususnya pejalan kaki.

b) Aktivitas pelaku kegiatan.

c) Peletakan main entranc, side entrance, dan service entrance.pembatasan yang jelas antara sirkulasi kendaraan, pedestrian demi keamanan pengunjung dan kelancaran sirkulasi di luar tapak.

d) Kemudahan, kejelasan, keamanan dan kenyamanan sirkulasi.

e) Pencapaian beberapa fungsi yang ada dalam bangunan.

Ada beberapa sirkulasi yang terjadi dalam panti rehabilitasi ini, yakni:

a) Sirkulasi pejalan kaki; hal yang perlu diperhatikan adalah kenyamanan bagi pejalan kaki, bersifat mengarahkan pejalan ke area bangunan.

b) Sirkulasi kendaraan; hal yang perlu diperhatikan yakni kemudahan memasuki area maupun meninggalkan area Panti Rehabilitasi, pemisahan kendaraan umum dan kendaraan khusus.

c) Sirkulasi barang; kelancaran arus datang dan keluarnya barang yang diangkut oleh kendaraan-kendaraan besar.

Pendekatan pencapaian untuk memperoleh arahan penentuan pintu masuk dan pintu keluar. Segi pencapaian ini disamping terpengaruhi oleh letak zona penerima, juga dipengaruhi oleh kesan yang ingin disampaikan oleh bangunan.

a) Main Entrance; merupakan pencapaian umum bagi pengunjung yang difungsikan sebagai jalan masuk dari luar dan ke dalam tapak. Persyaratannya adalah,

- Kemungkinan arah masuk terbesar

- Kemudahan pencapaian ke tapak bangunan

- Kelancaran arus lalu lintas di sekitarnya

b) Side Entrance, merupakan alternatif pencapaian bagi pengunjung yang difungsikan sebagai jalan dari dan ke luar tapak. Adapun hal-hal yang harus dipertimbangkan yaitu,

- Kejelasan dan kemudahan arus masuk dan keluar

- Menghindari adanya crossing sirkulasi dalam tapak

c) Service Entrance, alternatif pencapaian bagi sirkulasi kegiatan service.

2. Tinjauan Terhadap Kondisi Tapak

a. Sekitar tapak merupakan tanah lapang dan pemukiman yang cukup renggang.

b. Batas-batas tapak adalah

Utara : Lahan Kosong

Selatan : jalan utama (Jl. Aeropala- Hertasning Baru )

Timur : jalan setapak dan Lahan kosong

Barat : Jalan setapak dan kanal.

c. Untuk memudahkan sirkulasi, maka perlu dipisahkan antara jalan masuk dan keluar ke dalam luar tapak.

3. Tinjauan Tata Letak/Zoning

Hal-hal yang perlu dipertimbangkan (1) keadaan lingkungan, utamanya yang dapat mempengaruhi aktivitas dan mental si pengguna (2) kondisi dan potensi tapak (3) bukaan dan (4) adanya ruang-ruang yang membutuhkan suasana/keadaan khusus.

Pada Panti Rehabilitasi Narkotika ini pengklasifikasian zoning terbagi atas hierarki sifat kegiatan.

a. Zona Publik (umum)

1) Meliputi daerah parkir kendaraan dan ruang penerima (bangunanumum)

2) Letaknya harus mudah, dicapai dari gerbang pencapaian utama.

b. Zona semi Publik

1) Meliputi bangunan serbaguna dan lapangan olahraga.

2) Letaknya dekat dengan kelompok publik/umum tapi agak tertutup.

c. Zona Semi Private

1) Meliputi bagian pendidikan (ruang belajar, perpustakaan, workshop dan kerohanian)

2) Letaknya di antara publik dan daerah private serta mempunyai sifat sebagai daerah peralihan (buffer zone)

d. Zona private

1) Meliputi unit rehabilitasi dan unit hunian 
2) Letaknya jauh dari area publik dan semi publik, agar tidak terganggu dari kebisingan lalu lintas dankegiatan bersama.

e. Zona service

1) Meliputi bagian service (dapur, tempat cuci, laundry, mekanikal elektrikal, menara air) rumah direktur, asrama staff, ruamh staff

2) Letaknya dekat dengan bangunan bagian pelayananan.

4. Orientasi

a. Terhadap matahari

1. Orientasi bangunan sejajar dengan arah datang matahari (timur-barat)

2. Penggunaan over steck, lisplank yang lebar, dinding, bidang vertical, sunscreen, kanopi dan sebagainya

b. Terhadap arah angin

Memberikan peluang masuknya angin ke dalam bangunan dengan membuat bukaan baik dari segi ukuran yang besar maupun sistemnya dengan cross ventilation.

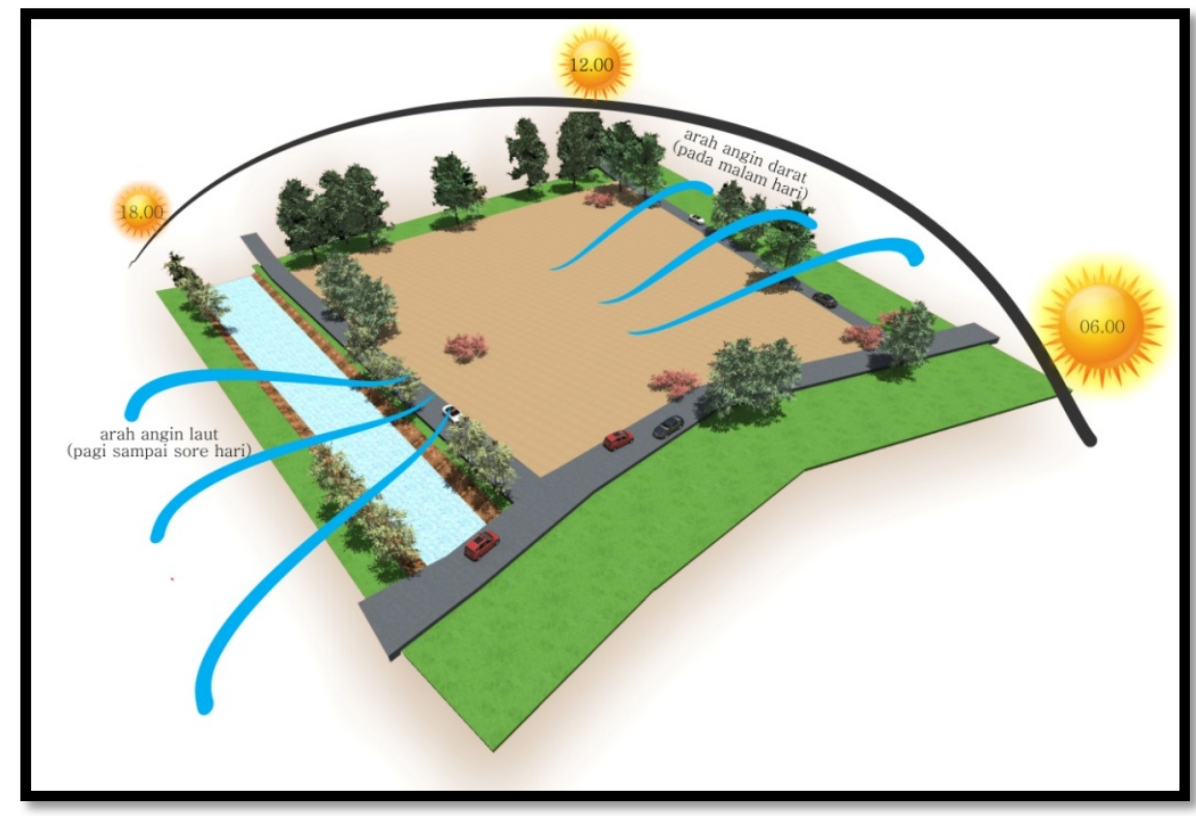

5. Pola Tata Massa, (Self Enclouse) bangunan rehabilitasi berfungsi juga sebagai pagar pembatas luar rehabiltasi, penerapan pola ini sesuai untuk security tingkat tinggi.

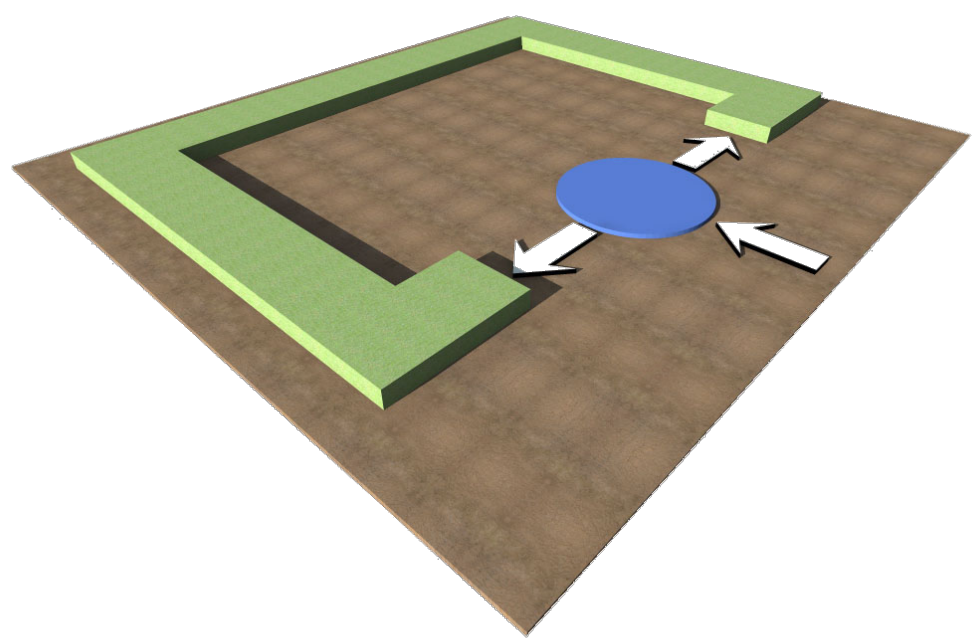




\section{Output Tapak}

Jalur masuk dibagi atas dua, bagian depan dan jalan utama untuk pasien dan keluarga pasien, jalan samping untuk pekerja sosial dan service.
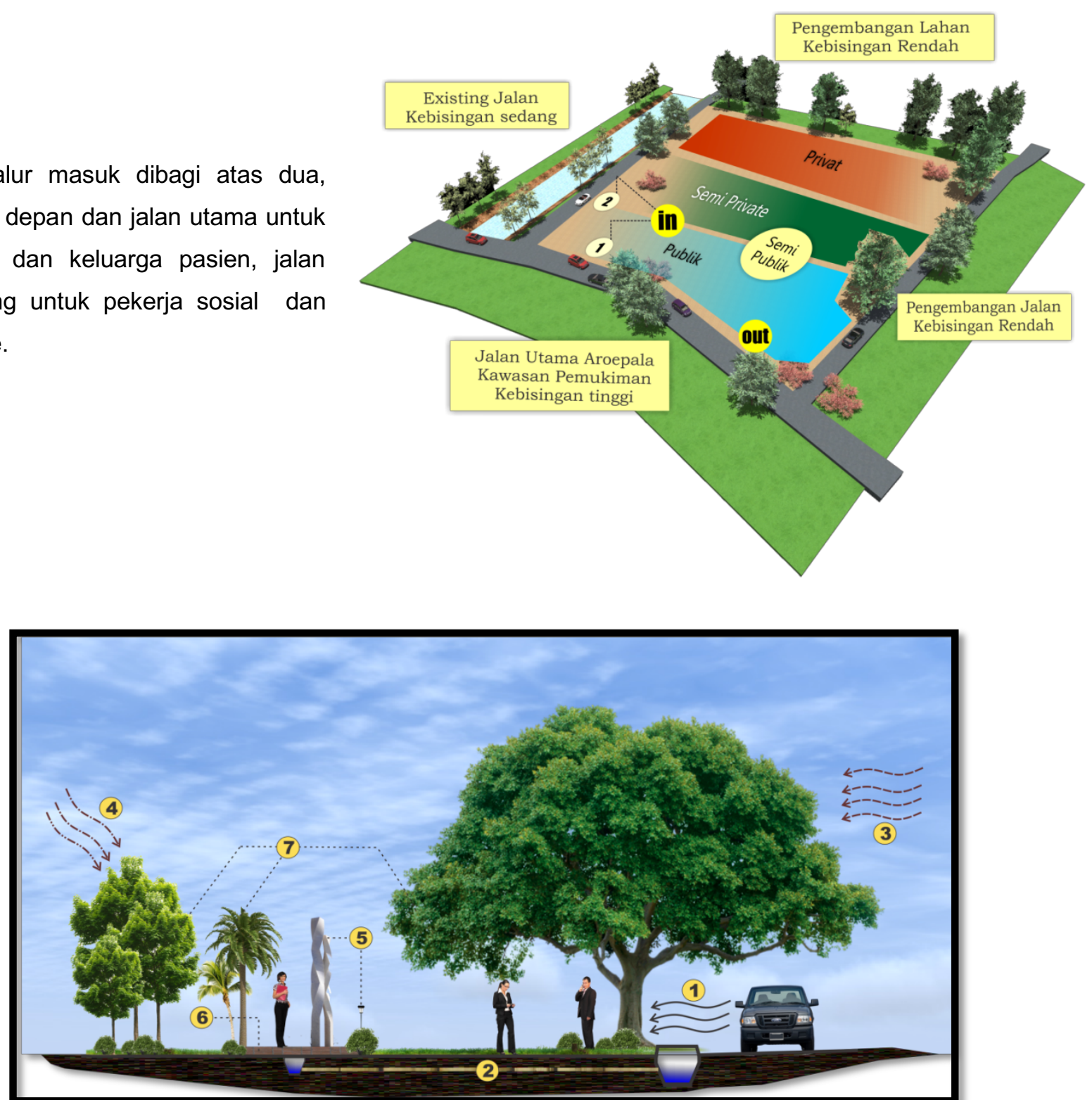

$(1,3)$ Pepohonan selain berfungsi untuk tempat berteduh, juga berfungsi untuk meredam kebisingan. Memfilter udara menjadi lebih segar dan bersih. (2) Saluran air setengah kotor, baik dari kamar mandi, westafel, dapur menuju langsung ke riol kota. (4) Matahari dapat dikurangi intensitasnya dengan menjadikan vegatasi sebagai perantara. (5) penggunaan dekorasi sebagai eye capture pada bagian-bagian tertentu ruang luar seperti lampu taman dan sculpture. (6) elemen keras dapat digunakan sebagai jalan setapak dalam taman. Batu alam maupun perkerasan semen. (7) vegetasi tidak hanya sebagai groundcover, pelindung ataupun pengarah tetapi juga sebagai pengikat ruang-ruang baik ruang yang ada secara fisik maupun tidak terlihat.

\section{Kebutuhan dan Pengelompokan Ruang}

Secara garis besar macam kebutuhan ruang dapat dikelompokkan berdasarkan fungsinya sebagai berikut;

a. Kelompok ruang administrasi

b. Kelompok ruang medik (rehabilitasi medis, psikologi, psikososial dan religi)

c. Kelompok hunian

d. Kelompok ruang penunjang

e. Kelompok ruang pelayanan 


\section{Rekapitulasi Keb.Ruang}

\begin{tabular}{|c|c|c|}
\hline No & Jenis Ruang & $\begin{array}{c}\text { Besaran } \\
\text { Ruang }\left(\mathrm{m}^{2}\right)\end{array}$ \\
\hline $\begin{array}{l}1 . \\
2 . \\
\\
\\
3 . \\
4 . \\
5 .\end{array}$ & $\begin{array}{l}\text { Bagian Administrasi } \\
\text { Bagian Medik } \\
\text { a. Unit Klinik } \\
\text { b. Unit Detoksifikasi } \\
\text { c. Unit Rehabilitasi Medik } \\
\text { d. Unit Rehabilitasi Psikologi } \\
\text { e. Unit Rehabilitasi Psikososial } \\
\text { f. Unit Rehabilitasi Psikoreligi } \\
\text { Unit Hunian } \\
\text { Fasilitas Penunjang } \\
\text { Fasilitas Service } \\
\text { Luas Lantai Bangunan } \\
\text { Sirkulasi } 15 \%\end{array}$ & $\begin{array}{c}487 \\
605 \\
551 \\
209 \\
1340.6 \\
1716 \\
540 \\
5737 \\
1715 \\
616 \\
13.516,6 \\
\mathbf{2 . 0 2 7 , 5}\end{array}$ \\
\hline Tot & al Luas Bangu & 15.543 \\
\hline
\end{tabular}

a) Area parkir pengunjung/penjenguk/pembesuk

Dari estimasi 200 orang pengunjung dengan perbandingan pengguna kendaraan pribadi mobil : motor : angkutan umum (pejalan kaki) $=30: 40: 30$, maka didapatkan :

Kebutuhan mobil ${ }^{30} / 100 \times 200=60$ mobil

Kebutuhan motor $40 / 100 \times 200=80$ motor

Luas $=\left(60 \times 15 \mathrm{~m}^{2}\right)+\left(80 \times 1,5 \mathrm{~m}^{2}\right)+($ flow $20 \%)$

$=1224 \mathrm{~m}^{2}$

b) Area parkir pengelola $\&$ staff medik

Parkir pengelola diasumsikan 100 orang, dengan perbandingan pengguna kendaraan pribadi mobil : motor :

angkutan umum (pejalan kaki) $=40: 50: 10$, maka didapatkan :

Kebutuhan mobil $40 / 100 \times 100=40$ mobil

Kebutuhan motor $50 / 100 \times 100=50$ motor

Luas $=\left(40 \times 15 \mathrm{~m}^{2}\right)+\left(50 \times 1,5 \mathrm{~m}^{2}\right)+($ flow $20 \%)$

$=810 \mathrm{~m}^{2}$

Jadi estimasi luas total terbangun $=$ bangunan + perparkiran

$$
=15.534 \mathrm{~m}^{2}+2034 \mathrm{~m}^{2}
$$

$=19.415 \mathrm{~m}^{2}$

Koefisien Luas Bangunan (KLB) $=2$ lantai (Hunian pasien, psikososial, psikologi)

$$
\begin{aligned}
& =(6630) / 2 \\
& =19.415-3165 \\
& =\mathbf{1 6 . 2 5 0 ~} \mathbf{~} 2 \text { (angka dibulatkan) }
\end{aligned}
$$

Building Coverage : $30 \%$ (BS) $70 \%$ (OS)

c) Luas terbangun ( $30 \%$ ) adalah $=\mathbf{1 6 . 2 5 0} \mathbf{~ m}^{2}$

d) Luas tidak terbangun ( $70 \%$ adalah $=60 \% / 40 \% \times 16.250 \mathrm{~m}^{2}$

$$
=24.375 \mathrm{~m}^{2}
$$

Jadi total luas lahan keseluruhan adalah $=16.250+24.375$

$=40.625(4,1 \mathrm{Ha})$

\section{Penampilan Bangunan}

Sebelumnya telah dijelaskan bahwa konsepsi penampilan bangunan akan diterapakan arsitektur posmodern dengan gaya atau aliran hitoricism dengan elemen-elemen klasik seperti ionik, dorik, corintin dengan perpaduan elemen dari banguna itu sendiri.

Adapun faktor-faktor nonarsitektural yang perlu diperhatikan adalah

a) Fungsi bangunan sebagai pelayanan sosial

b) Merupakan sarana pembinaan dan pendidikan untuk mengatasi residen penyalahgunaan narkotika

c) Kesan hangat, aktif dan monumental. Monumental disini bukan berarti selalu berhubungan dengan skala megah dibanding skala manusia. Dengan memandang secara luas lagi, monumen berarti ada cipta berkesan, rasa teringat karena sesuatu hal yang tidak biasanya, tidak lumrah, jarang bahkan sesuatu yang baru. 
a. Modul

Modul yang digunakan adalah 30x30 cm dengan mempertimbangkan ruang gerak dari masing-masing fungsi dan kegiatan dikaitkan dengan besaran perabotan.

b. Sistem Struktur

Hal- hal yang perlu dipertimbangkan dalam penentuan sistem struktur bangunan, antara lain:

1) Struktur cukup kuat dan ekonomis mampu mendukung penampilan bentuk bangunan.

2) Kuat menahan beban-beban, antara lain: beban hidup, beban mati, dan beban angin.

3) Mudah dalam pelaksanaan dan perawatan.

4) Kondisi site (kemungkinan pelaksanaan di lapangan). Daya dukung tanah pada site.

Beberapa jenis dan alternatif sistem struktur terbagi atas tiga kelompok besar, yaitu :

a. Sistem struktur bawah (sub structure)

Yang perlu diperhatikan dalam sistem struktur bawah, yaitu :

1) Sesuai dengan daya dukung tanah setempat

2) Kemudahan pelaksanaan dan efek gangguan yang sekecil-kecilnya terhadap lingkungan di sekitarnya

3) Struktur yang berfungsi sebagai penopang bangunan, yang akan menyalurkan beban bangunan terhadap tanah.

Sistem struktur yang direncanakan untuk upper struktutr (struktur atap) yaitu dengan menggunakan sistem rangka baja (stell trus dan space truss). Dengan material penutup atap yaitu zincalum (seng aluminium) yang mudah dibentuk sesuai dengan keinginan. Dengan pertimbangan :

1) Memiliki kemampuan untuk menahan beban struktur bentangan lebar.

2) Mudah dalam pelaksanaan

3) Daya tahan yang tinggi terhadap angin dan cuaca.

\section{Tata Ruang Dalam}

a. Pola tata ruang dalam membutuhkan;

(1) Mempunyai sirkulasi dan orientasi yang mudah

(2) Memungkinkan pengawasan visual pengasuh

(3) Mendukung pasien untuk dapat beradaptasi dan melakukan interaksi dengan lingkungannya

(4) Menghindari bagian-bagian yang tajam dari bangunan itu sendiri maupun furniture yang digunakan

Olehnya itu, hal di atas dapat dicapai dengan menggunakan sistem sirkulasi yang tidak bercabang-cabang dan pemggunaan ruang bersama sebagai pusat dari komunikasi terkecil dalam hunian. (sistem radial plan)

b. Warna

Warna sangat berpengaruh dalam panti rehabilitasi ini sebab dapat mempengaruhi psikologi dan emosi pasien maka warna yang dipergunakan

(1) Dihindarkan warna-warna panas seperti merah dan orange. Karena warna tersebut dapat mempengaruhi denyut nadi dan pernapasan.

(2) Menggunakan waran-warna sejuk (hijau,biru dll) sebab dapat memberi dampak ketenangan pasien

(3) Warna diusahakan tidak meyilaukan

c. Material

Bahan bangunan yang dimaksud adalah penggunaan material bangunan baik struktur maupun non struktur. Untuk elemen non struktur :

(a) Lantai

Syarat dari lantai :

(1) Dapat menahan beban yang datang dari perlengkapan ruang dan manusia yang ada di dalamnya.

(2) Tidak terlalu licin, Tidak menghantarkan panas

(3) Berfungsi sebagai akustik ruang dengan beberapa sistem modifikasi akustik disesuaikan dengan fungsi ruang.

(b) Dinding

(1) Tahan terhadap pengaruh bahan kimia dam mudah dibersihkan.

(2) Sebagai pelindung terhadap pengaruh alam, misalnya radiasi matahari, pelindung terhadap angin dan hujan.

(3) Berfungsi sebagai akustik ruang dengan beberapa sistem modifikasi akustik disesuaikan dengan fungsi ruang.

(c) Plafond

(1) Tidak menimbulkan radiasi panas

(2) Kuat dan awet

(3) Sebagai akustik ruangan (accoustical ceiling board)

Ketinggian plafond disesuaikan dengan tuntutan masing-masing ruang.

Secara umum, material yang digunakan mencakup sebagai berikut 
1. Penggunaan bahan tidak membahayakan, seperti dengan bahan yang bertekstur halus, lunak dll

2. Meminimalisasi penggunaan material yang mudah pecah (kaca,cermin)

3. Material yang mudah dalam maintenance dan awet

4. Kedap suara khusus untuk ruang-ruang tertentu saja missal ruang konsultasi psikologi, ruang psikater dll.

\section{Plan \& View}

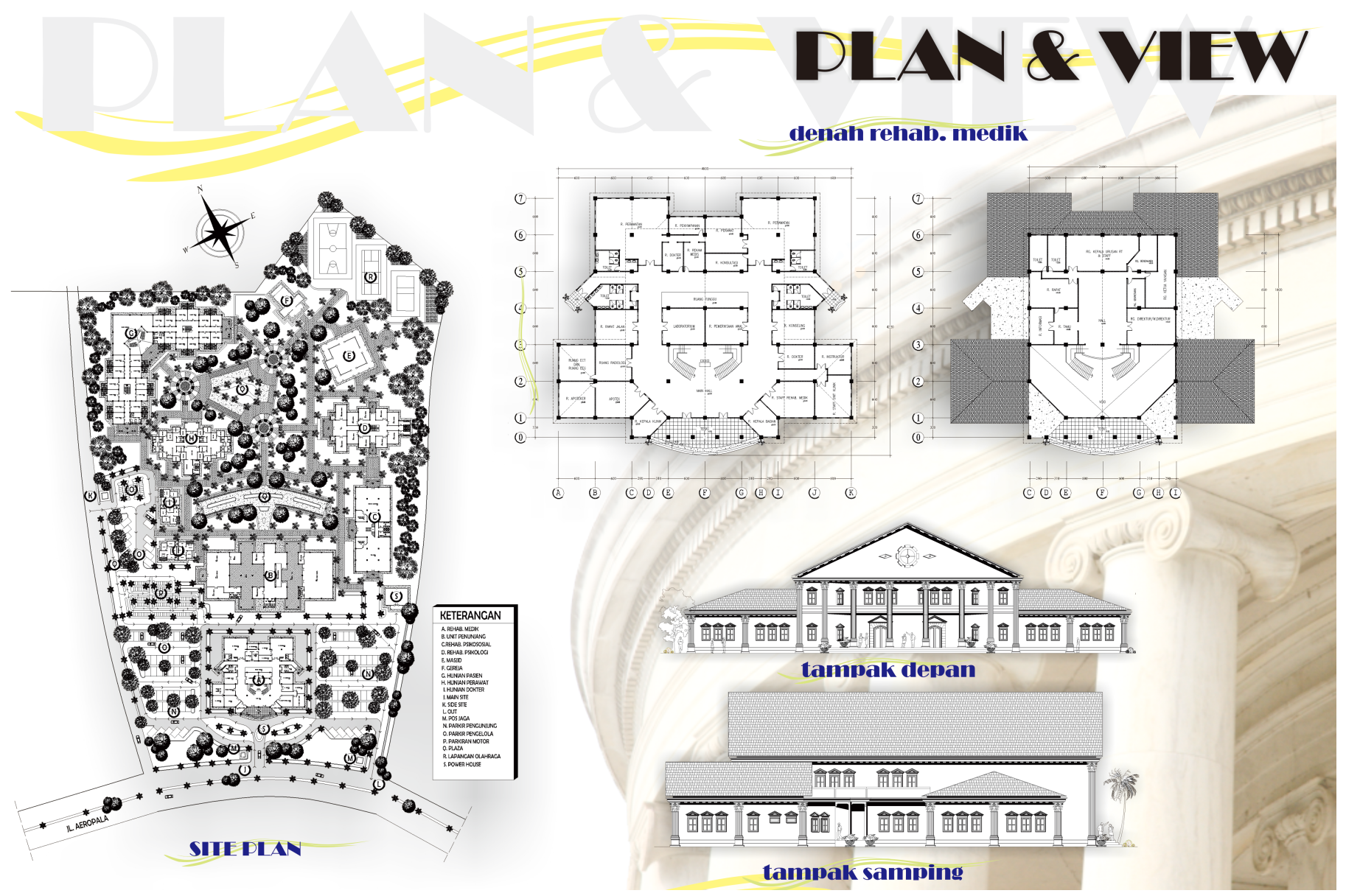




\section{DLAN \& VIEW}

\section{denah rehab. psikologi}
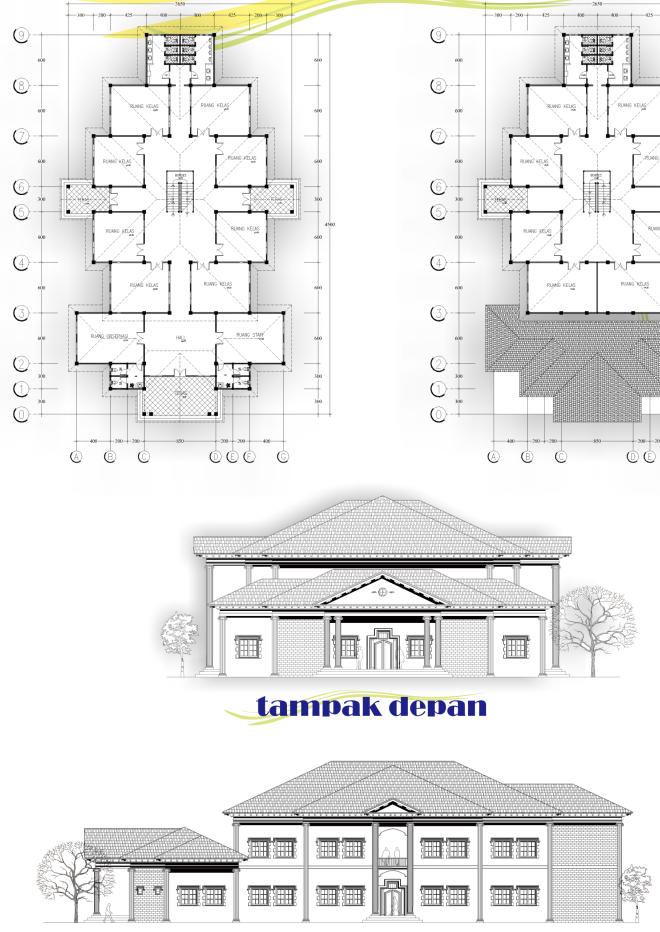

tampak samping

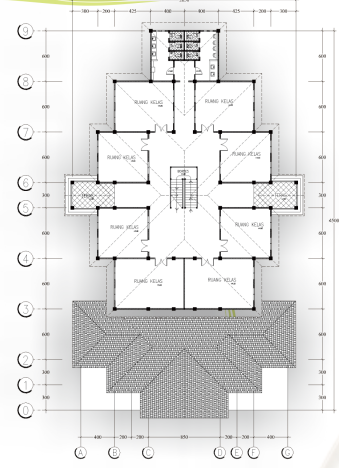

denah hunian perawat

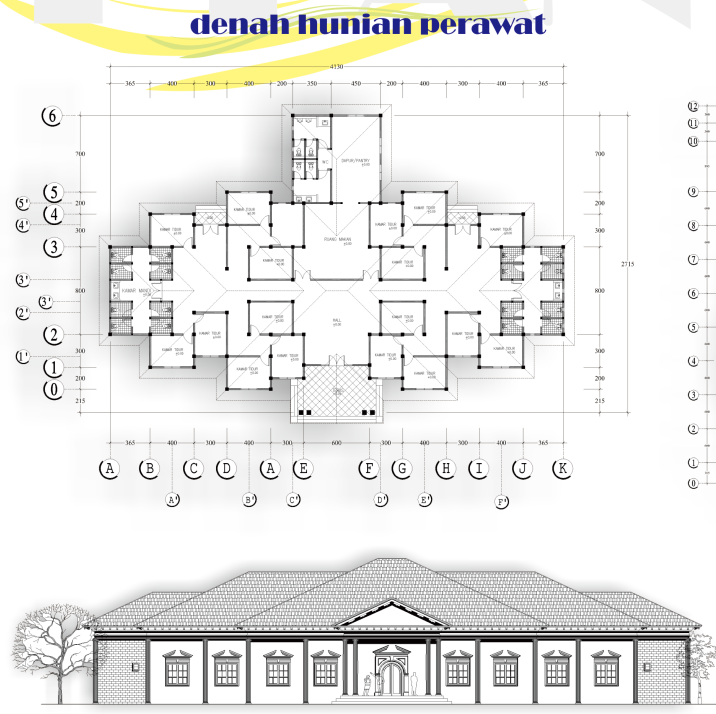

tampak depan

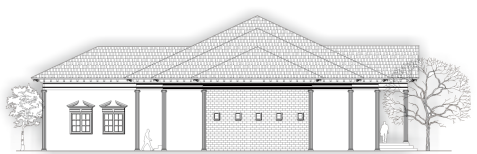

tammak samping
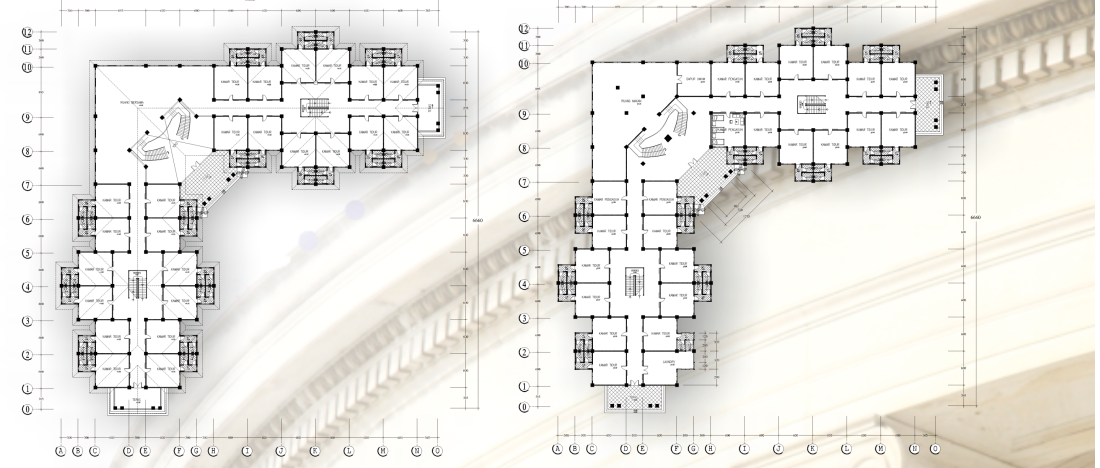

(4)

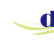

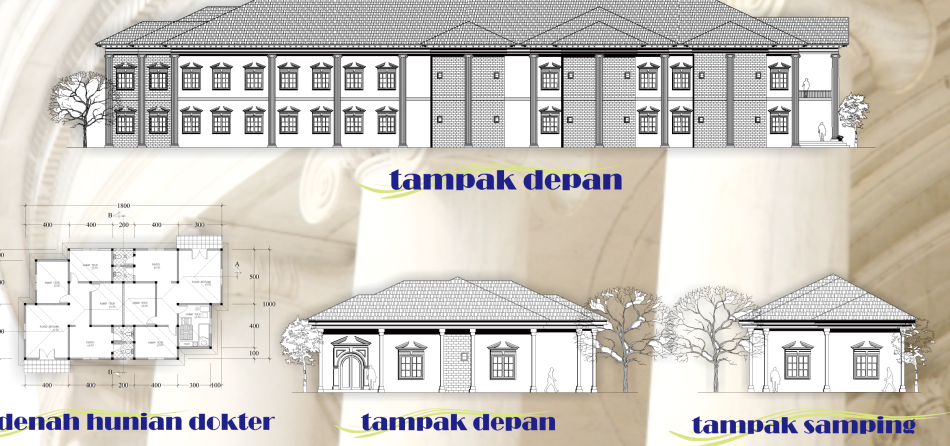




\section{DLAN \& VIEW}

TAMDAK KOMDIEKSA

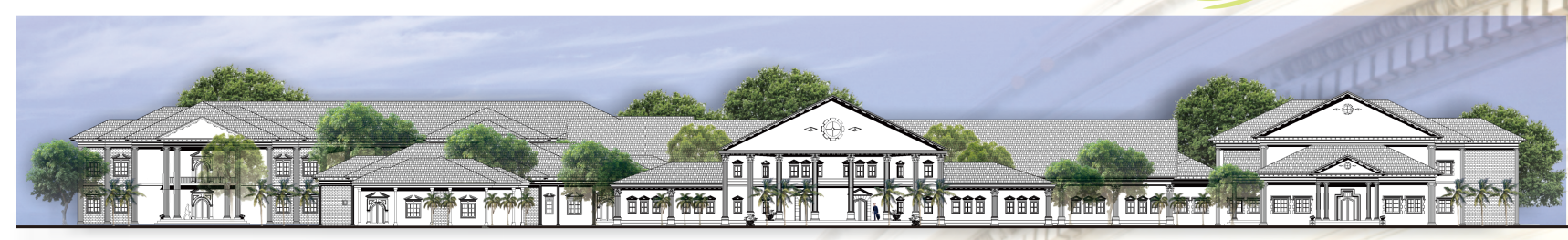

TAMDAKKOMDIEKS B
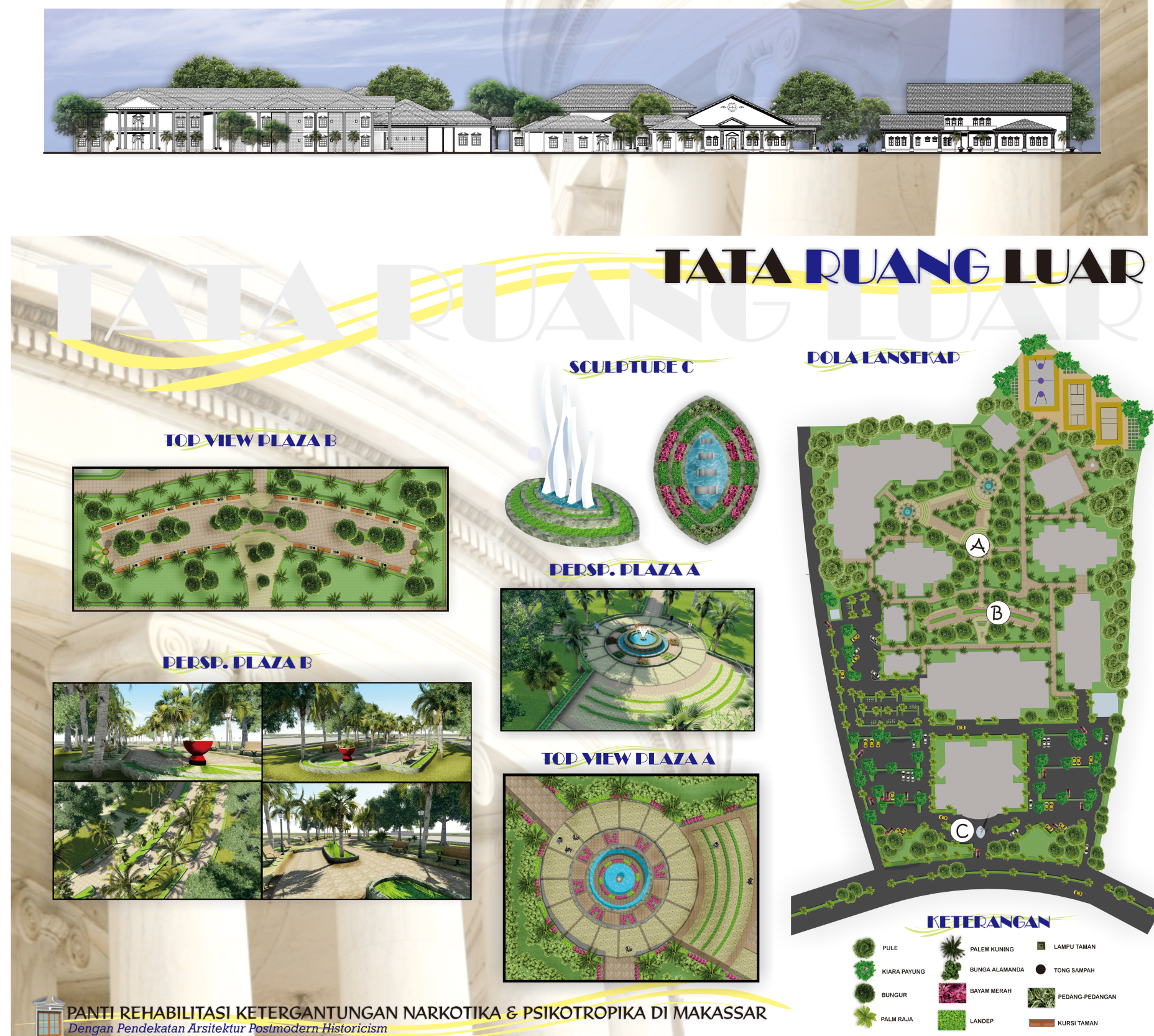

PANTI REHABILITASI KETERGANTUNGAN NARKOTIKA \& PSIKOTROPIKA DI MAKASSAR Dengan Pendekatan Arsitektur Postmodern Historicism

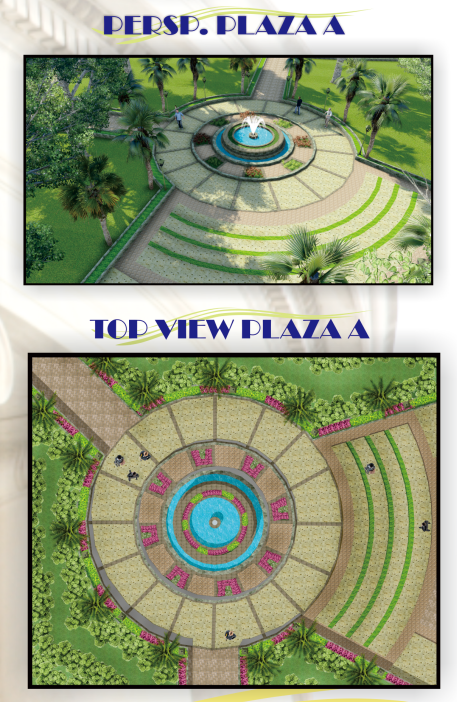

Postmodern Historicism 


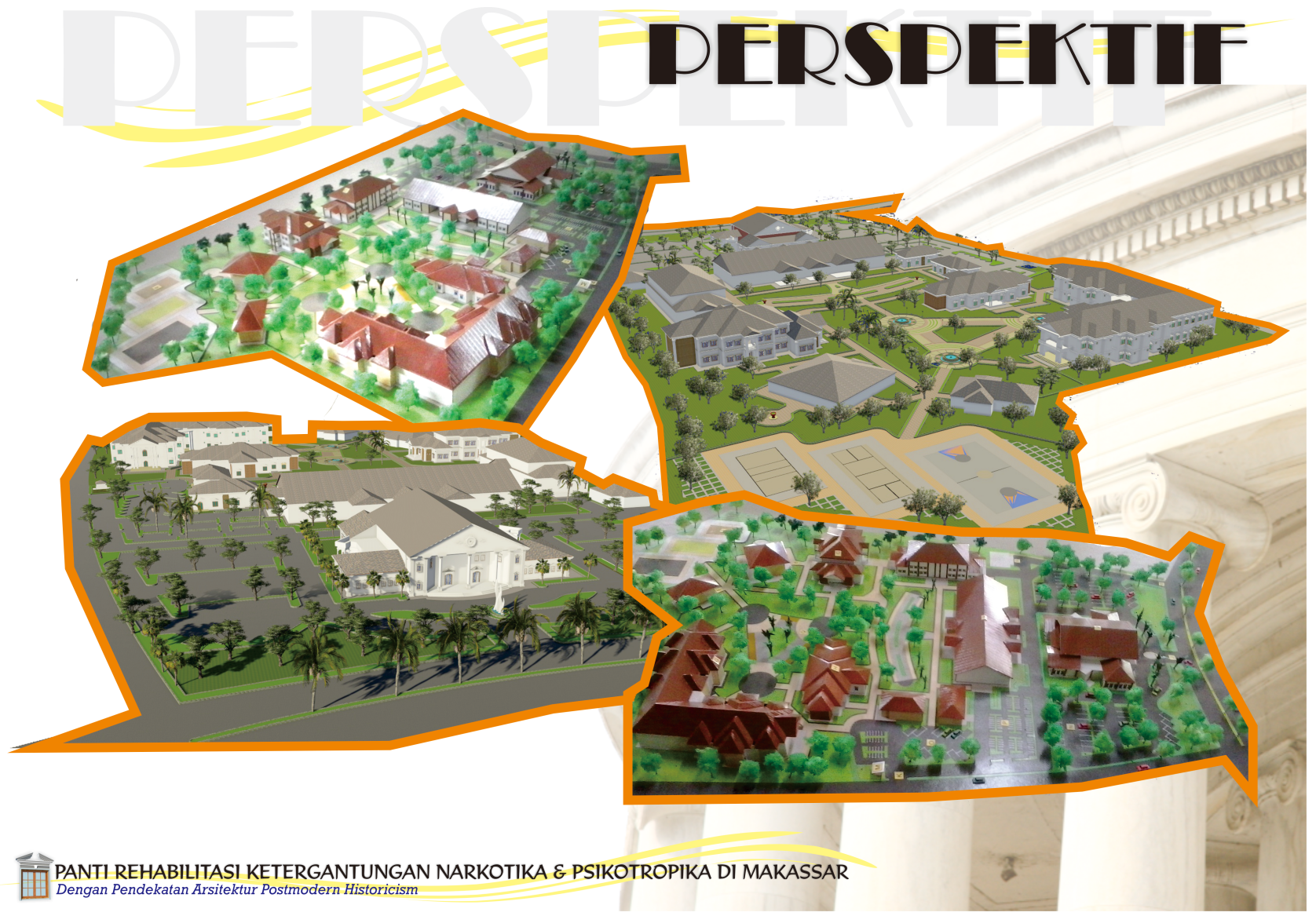

\section{DAFTAR PUSTAKA}

Lubis.Satria Hadi. 2003. Total Motivation. Yogyakarta:pustaka pelajar.

Hawar, Prof.Dr.H.Psikiater.2002.Rehabilitasi Pengguna Narkotika \& Psikotropika.Jakarta :FK-UI

Undang-undang narkotika \& psikotropika. 1999. Jakarta: sinar Grafika Offset

Ernst, Neufert..1996.Data Arsitektur (1 dan II). Jakarta:Erlangga

Panero,Julius,dkk.2003. Dimensi manusia dan ruang interior. Jakarta:erlangga

Chiara, Joseph. 1983. Time Saver Standar For Building Types. Singapore: Mc Craw hill International Company

BPS Kota Makassar.2010. Makassar dalam Angka 2010

Artikel IImiah. Ginandjar Kartasasmita. 1997. Karakter dan struktur masyarakat modern Indonesia. Jogyakarta.

Tribun Timur News. Oktober.6. 2011

Bertens, Hans. The Idea of the Postmodern A History. (Ebook)

Widyaningsih, Lilis. Post-modernisme dalam Karya Arsitektur Frank O. Gehry (ebook)

Machmud, Mauraga. 2005. Psikologi Arsitektur Post Modern. Makassar: Rona Jurnal Arsitektur FT Unhas Vol.2 No.01

Poerbo, H.1996. Utilitas Bangunan.Jakarta.

Harisah, Afifah.dkk. Ekletisme dan Arsitektur Ekletik. Yogyakarta: UGM press

M.Haris,Cyril. 1997.Illustrated Dictionary Historic Architecture.New York:Dover. 